\title{
Konseling Islami: Suatu Alternatif bagi Kesehatan Mental
}

\author{
Muzaki ${ }^{1}$, Agung Saputra ${ }^{2}$ \\ ${ }^{1}$ Program Studi Bimbingan Konseling Islam, Fakultas Ushuluddin Adab dan Dakwah, \\ IAIN Syekh Nurjati Cirebon \\ Email Penulis ${ }^{1}$ : kemalzaki66@gmail.com \\ ${ }^{2}$ Program Studi Bimbingan Konseling Islam, Fakultas Ushuluddin Adab dan Dakwah, \\ IAIN Syekh Nurjati Cirebon \\ Email Penulis 2: agungsaputra313@gmail.com
}

\begin{abstract}
Abstrak
Konseling Islami merupakan suatu proses pemberian bantuan terhadap individu agar mampu dan mempunyai kesadaran akan kehidupannya sebagai makhluk Allah SWT, sehingga hidup dengan ketentuan dan petunjuk Allah SWT serta mengembangkan potensi fitrah yang dimiliki demi mencapai kebahagiaan di dunia dan di akhirat. Konseling Islami berperan untuk membantu individu yang sedang mengalami masalah agar dapat kembali menemukan potensi dirinya dan dengan keimanannya diharapkan individu tersebut dapat mengatasi segala kesulitan yang sedang dihadapi. Inti tujuan konseling Islami adalah meningkatkan iman, Islam, dan ihsan bagi setiap individu yang diberi konseling hingga menjadi pribadi yang utuh, dan pada akhirnya diharapkan mereka semua akan hidup bahagia di dunia dan di akhirat. Menggabungkan peran agama ke dalam definisi sehat, maka akan didapatkan paradigma sehat yang komprehensif karena akan berdampak baik dalam kehidupan manusia manakala kepribadian yang ada pada diri manusia disesuaikan dengan konsepsi ajaran agamanya. Layanan konseling Islami merupakan suatu layanan yang tidak hanya mengupayakan manusia untuk bermental sehat dan hidup sejahtera, melainkan juga yang dapat menuntun kepada hidup yang sakinah, batin merasa tenang dan tenteram karena selalu dekat dengan Tuhan Yang Maha Esa. Kenyataan ini menunjukkan bahwa layanan konseling terlebih dalam bidang keagamaan keberadaannya sangat diperlukan masyarakat secara luas.
\end{abstract}

Kata Kunci: Konseling Islami; Kesehatan Mental.

\section{PENDAHULUAN}

Dalam menghadapi era globalisasi yang membawa dampak pembauran peradaban dan kebudayaan antar bangsa, serta membawa dampak bergesernya masyarakat agraris ke masyarakat industri, banyak didapati individu-individu yang sibuk dengan permasalahan duniawi juga paham materialistik dan individualistik yang berpengaruh negatif dalam segi- 
segi kehidupan manusia. Dan kenyataan di era globalisasi sekarang ini, semakin majemuknya kehidupan masyarakat dan sebagainya jelas telah membawa perubahan nilai-nilai dan normanorma yang membingungkan, meresahkan, dan menimbulkan problem-problem kehidupan yang pelik, yang tidak sedikit melahirkan sikap-sikap dan perilaku manusia yang destruktif seperti sombong, kikir, zalim, ingkar, mau menang sendiri, dan sebagainya (Amin, 2013: 24).

Sikap dan perilaku negatif seperti yang diuraikan di atas jelas merupakan bentuk penyimpangan dari perkembangan fitrah beragama manusia yang telah diberikan oleh Tuhan Yang Maha Esa. Dalam kondisi penyimpangan dari perkembangan fitrah yang demikian itu seorang individu akan terlepas hubungannya dengan Tuhan, dan dapat pula mengakibatkan individu tersebut terlepas hubungannya dengan sesama manusia serta alam sekitar, sehingga yang ia lakukan hanya membuat kerusakan baik bagi dirinya sendiri, orang lain, maupun lingkungan di mana ia tinggal (Amin, 2013: 25).

Dalam kondisi yang terputus hubungan baik dengan Tuhan maupun dengan sesama manusia dan lingkungan, individu tersebut merasa tidak memiliki pegangan yang kuat sebagai pedoman hidupnya. Individu yang demikian itu akhirnya merasa terombang-ambing dalam kesendiriannya, ia bisa mengalami stres bahkan depresi. Inilah tragedi dunia modern, yang tidak semua mendatangkan keberuntungan dan kebermanfaatan dalam artian yang positif, namun lebih banyak ke arah negatif berupa kemanusiaan modern sebagai kesengsaraan rohaniah. Modernitas pun telah menyeret manusia pada kegersangan spiritual. Menurut Mulyadi (2017: 21-22) ekses ini merupakan konsekuensi logis dari era globalisasi yang terabaikan, yang pada akhirnya mendatangkan berbagai gangguan kejiwaan.

Fitrah manusia dalam pandangan Anwar Sutoyo (2015: 23-24) adalah keadaan atau kondisi penciptaan yang terdapat dalam diri manusia yang menjadikannya berpotensi mampu mengenal Tuhannya, karena fitrah tersebut telah ditanamkan oleh Tuhan Sang Maha Pencipta dalam diri setiap insan sejak awal diciptakan. Dengan fitrah tersebut manusia akan cenderung kepada keindahan, kebaikan, pengorbanan, kesetiaan, pemujaan, dan sebagainya. Fitrah manusia yang berkembang secara optimal akan mengantarkan kepada suatu realitas yang Maha Sempurna, tanpa cacat, tanpa batas, dan tanpa akhir, karena sesungguhnya kepada Tuhanmulah berakhirnya segala sesuatu (Shihab, 2013: 103-104).

Dengan berpandangan ini, Anwar Sutoyo memperkenalkan konsep konseling Islami sebagai proses pemberian bantuan terhadap individu untuk belajar mengembangkan fitrah dan atau kembali kepada fitrahnya sebagai manusia, dengan cara memberdayakan potensipotensi yang ada pada manusia, seperti iman, akal pikiran, panca indra, dan kekuatankekuatan positif lainnya yang ada pada manusia untuk mengubah corak kehidupannya. Dalam hal ini potensi iman dipandang sebagai inti untuk mendorong dan mengarahkan potensi-potensi lainnya ke arah yang lebih postif, karena jika iman seseorang telah berkembang dan berfungsi dengan baik, maka potensi-potensi yang lainnya pun akan berkembang dan berfungsi dengan baik pula. Oleh sebab itulah, dalam pemikiran Anwar Sutoyo (2015: 22-24) layanan konseling Islami sepatutnya lebih memfokuskan pada pengembangan fitrah manusia berupa iman. 
Di sinilah letak salah satu urgensi penggalian konsep konseling Islami sebagai pendekatan dalam upaya membantu masyarakat modern. Seperti yang telah dijelaskan di muka bahwa, bahaya yang dihadapi masyarakat modern saat ini adalah akibat kemajuan ilmu pengetahuan dan teknologi di satu pihak, dan kelengahan manusia dalam menyadari kelemahan-kelemahannya sehingga menjadikannya melupakan unsur kerohanian yang ada dalam dirinya. Di era globalisasi ini, konseling Islami menawarkan cara untuk menjadi dikenal dan didengar. Selain itu, konseling Islami juga merupakan suatu layanan yang mengupayakan mental sehat dan sejahtera, dan juga dapat menuntun manusia kepada hidup yang sakinah, agar hidup merasa tenang dan batin merasa tenteram karena selalu dekat dengan Tuhan (Musnamar, 1992: 11-12).

Mental sehat pada manusia adalah pengetahuan dan perbuatan yang dapat mengembangkan dan memanfaatkan segala potensi, bakat dan pembawaan yang ada semaksimal mungkin sehingga menciptakan penyesuaian diri antara dirinya sendiri dengan orang lain dan lingkungannya yang berlandaskan atas keimanan dan ketakwaan, yang pada akhirnya membuat hidup lebih bermakna dan bahagia baik di dunia maupun di akhirat (Daradjat, 1990: 11).

Berdasarkan uraian di atas, maka menunjukkan bahwa keberadaan layanan konseling Islami sangat dibutuhkan oleh masyarakat modern saat ini secara luas untuk menetralkan pengaruh teknologi yang telah menghilangkan kepribadian dan fitrahnya sebagai manusia. Oleh karena itu, kajian mengenai layanan konseling Islami menjadi sangat penting bagi masyarakat modern dalam upaya menggali kembali nlai-nilai keagamaan dan spiritual yang berangsur-angsur mulai dilupakan.

\section{PEMBAHASAN}

\section{Konseling Islami}

Secara etimologi istilah konseling berasal dari bahasa latin yaitu "conselium" yang berarti "dengan" atau "bersama" yang dirangkai dengan "menerima" atau "memahami". Sedangkan dalam bahasa Anglo Saxon, istilah konseling berasal dari kata "sellan" yang memiliki arti "menyerahkan" atau "menyampaikan" (Ramayulis dan Mulyadi, 2016: 110). Sedangkan dalam literatur lain dijelaskan bahwa, istilah konseling berasal dari kata "counseling" yaitu dari kata benda "counsel" yang berarti nasihat (Anwar, 2014: 2). Sejalan dengan ini, Samsul Munir Amin menjelaskan bahwa, kata "counseling" adalah kata dalam bentuk masdhar dari "to counsel" yang secara etimologi berarti "to give advice" atau memberikan saran dan nasihat (Amin, 2013: 10).

Kemudian secara terminologi, para ahli pun beragam pendapat dalam mendefinisikan arti konseling. Dalam pandangan R. L. Wolberg, konseling merupakan suatu bentuk pemberian bantuan terhadap individu agar individu tersebut lebih mengerti tentang dirinya sendiri, sehingga dapat memperbaiki kesulitan yang berhubungan dengan lingkungan atau agar dapat memperbaiki kesulitan penyesuaian (Ramayulis dan Mulyadi, 2016: 111). Robinson berpendapat bahwa konseling adalah sebuah bentuk hubungan antara 
dua orang, di mana yang seorang disebut dengan klien dan dibantu untuk lebih mampu menyesuaikan diri secara efektif terhadap dirinya sendiri dan lingkungannya (Yusuf dan Nurihsan, 2005: 7).

Dewan kehormatan American Counseling Association (ACA), yaitu organisasi terbesar wadah konselor di Amerika mendefinisikan konseling sebagai aplikasi kesehatan mental, prinsip-prinsip psikologi atau perkembangan manusia, melalui intervensi kognitif, afektif, perilaku, atau sistemik; strategi untuk menangani kesejahteraan, pertumbuhan pribadi, atau perkembangan karier, serta kelainan (Gladding, 2015: 6).

British Association of Counseling (BAC) menegaskan bahwa kata "konseling" mencakup bekerja dengan banyak orang dan hubungan yang mungkin saja bersifat pengembangan diri, dukungan terhadap krisis, psikoterapis, bimbingan atau pemecahan masalah. Tugas konseling menurut BAC adalah memberikan kesempatan kepada "klien" untuk mengeksplorasi, menemukan, dan menjelaskan cara hidup lebih memuaskan dan cerdas dalam menghadapi sesuatu (McLeod, 2015: 5).

Feltham dan Dryden secara detail menerangkan tentang konseling. Menurutnya, konseling merupakan hubungan baik yang ditandai dengan pengaplikasian satu atau lebih teori psikologi dan satu set keterampilan komunikasi yang dikenal, dimodifikasi melalui pengalaman, intuisi, dan faktor interpersonal lainnya, terhadap perhatian, problem, atau inspirasi klien yang paling pribadi. Bagi Feltham dan Dryden, etos terpenting dalam proses konseling adalah lebih bersifat memfasilitasi ketimbang memberi saran atau menekan.

Konseling dapat terjadi dalam jangka waktu yang pendek atau panjang, mengambil tempat baik di setting organisasional maupun pribadi dan dapat atau tidak dapat tumpangtindih dengan masalah kesehatan pribadi seseorang baik yang bersifat praktis maupun medis. Kedua aktivitas yang berbeda tersebut dilaksanakan oleh individu yang setuju untuk melakoni peran sebagai konselor dan klien. Konseling adalah sebuah profesi yang dicari oleh orang yang berada dalam tekanan atau dalam kebingungan, yang berhasrat berdiskusi dan memecahkan semua itu dalam sebuah hubungan yang lebih terkontrol dan lebih pribadi dibandingkan pertemanan, dan mungkin lebih simpatik atau tidak memberikan cap tertentu dibandingkan dengan hubungan pertolongan dalam praktik medis tradisional atau setting psikiatrik (McLeod, 2015: 7-8).

Beberapa ahli di Indonesia juga mendefinisikan konseling secara beragam. Menurut Prayitno, konseling bisa dipahami sebagai proses pemberian bantuan yang dilakukan melalui wawancara oleh seorang ahli (disebut konselor) kepada individu yang sedang mengalami sesuatu masalah (disebut klien) yang bermuara pada teratasinya masalah yang dihadapi oleh klien (Prayitno dan Amti, 2013: 103). Thohirin mengemukakan bahwa konseling merupakan kontak atau hubungan timbal balik antara dua orang (konselor dan klien) untuk menangani masalah klien, yang didukung oleh keahlian dan dalam suasana yang laras integrasi berdasarkan norma-norma yang berlaku untuk tujuan yang berguna bagi klien. Sedangkan konseling dalam pandangan Sri Mulyani Martaniah adalah suatu proses pemberian bantuan terhadap individu, yang menghasilkan suatu perubahan dalam kurun waktu tertentu, dalam usaha mencapai suatu tujuan (Ramayulis dan Mulyadi, 2016: 112-113). 
Pada dekade delapan puluhan di Indonesia telah muncul suatu pendekatan konseling yang dibangun dari perspektif agama Islam. Usaha publikasi sistematik dalam menggali dan mencari konsep konseling yang berdasarkan pada ajaran Islam ini kemudian dikenal dengan sebutan konseling Islami. Konseling Islami merupakan suatu layanan pemberian bantuan terhadap individu maupun kelompok dalam suatu masyarakat yang mengalami masalah emosi atau psikologi serta tingkah laku yang dibangun berdasarkan pada ajaran Islam, yang bersumber dari Al-Qur'an dan As-sunnah (Musnamar, 1992: 9-10). Secara umum, baik konseling Islami maupun konseling yang diperkenalkan oleh konsep Barat dipandang sebagai sesuatu yang baik, efektif, atau relevan oleh mereka yang hidup sekarang dalam budaya modern. Konseling Islami dan konseling pada umumnya juga sama-sama menyajikan cara untuk menolong manusia dalam menghadapi setiap perubahan, baik perubahan dalam dirinya maupun perubahan sosial.

Namun, secara fundamental terdapat perbedaan antara konseling Islami dengan konseling secara umum. Perbedaan tersebut yaitu konseling secara umum tidak menghubungkan masalah Tuhan dan agama dalam proses konseling, atau dalam layanan konseling ini semua berpusat kepada manusia dan sama sekali tidak berkaitan serta tidak dikaitkan dengan eksistensi Tuhan (antroposentris). Di lain pihak, konseling Islami justru berpusat kepada Tuhan Sang Maha Pencipta, yaitu Allah SWT (teosentris). Setiap langkah dan gerak konseling Islami harus dikaitkan dengan ajaran Islam yang berdasarkan Al-Qur'an dan Sunnah Nabi. Menurut Thohari Musnamar, meskipun terdapat perbedaan konsep dasar, sudut pandang, dan wawasan antara konseling Islami dengan konseling secara umum, namun itu tidak berarti bahwa konseling Islami menjadi ekslusif menutup diri dari dunia sekelilingnya (Musnamar, 1992: 17).

Dalam pandangan Saiful Akhyar Lubis, konseling Islami adalah layanan bantuan konselor terhadap klien untuk menumbuhkembangkan kemampuannya dalam memahami dan menyelesaikan masalah serta mengantisipasi masa depan dengan memilih alternatif tindakan terbaik demi mencapai kebahagiaan hidup dunia akhirat di bawah naungan ridha dan kasih sayang Allah SWT, serta membangun kesadarannya untuk menempatkan Allah SWT sebagai Konselor Yang Maha Agung (Lubis, 2008: 22). Kemudian Saiful Akhyar Lubis mengemukakan bahwa konseling Islami merupakan suatu proses konseling yang berorientasi pada ketenteraman hidup manusia baik di dunia maupun di akhirat. Pencapaian rasa tenteram itu adalah melalui upaya pendekatan diri kepada Allah SWT, karena dengan upaya pendekatan tersebut akan dicapai pula segala perlindungan dari-Nya (Lubis, 2008: $63)$.

Menurut Musari, konseling Islami bermakna menuntun konseli ke arah mendekatkan diri kepada Allah SWT melalui amal ibadah yang dilakukan dengan penuh Khusyu', sehingga pada gilirannya ia dapat memiliki hati yang sehat dan bersih, jiwa yang tenteram dengan seperangkat sifat-sifat terpuji, serta dapat merasakan hidup tenang dan bahagia untuk pencapaian kehidupan berperilaku dengan akhlak orang Muslim yang 
sempurna sebagai realisasi dari tuntunan pembawa Islam yaitu Nabi Muhammad SAW (Musari. 2011: 112).

Secara garis besar atau secara umum, tujuan konseling Islami adalah membantu individu untuk mewujudkan dirinya sebagai manusia yang seutuhnya agar mencapai kebahagiaan hidup di dunia dan di akhirat. Individu yang dimaksud di sini adalah orang yang diberi konseling, baik perorangan maupun kelompok. Sedangkan yang dimaksud dengan "Mewujudkan diri sebagai manusia seutuhnya" berarti mewujudkan diri sesuai dengan hakikatnya sebagai manusia untuk menjadi manusia yang selaras dengan perkembangan unsur dirinya dan selaras dengan pelaksanaan fungsi atau kedudukannya sebagai makhluk Allah yang religius, makhluk individu, makhluk sosial, dan sebagai makhluk berbudaya (Musnamar, 1992: 33).

Bagi Achmad Mubarok, tujuan konseling Islami ialah membantu individu agar memiliki pengetahuan tentang posisi dirinya dan memiliki keberanian mengambil keputusan untuk melakukan suatu perbuatan yang dipandang baik, benar, dan bermanfaat untuk kehidupannya di dunia dan untuk kepentingan akhiratnya (Mubarok, 2000: 89). M. Arifin menyebut tujuan pokok konseling Islami adalah membantu individu supaya memiliki religious reference (sumber pegangan keagamaan) dalam pemecahan problem-problem kehidupan, dan untuk membantu individu agar dengan kesadaran serta kemampuannya bersedia mengamalkan ajaran agamanya (Amin, 2013: 39).

Secara lebih khusus Badawi (dalam Ramayulis dan Mulyadi, 2016: 135-136) merumuskan tujuan konseling Islami ke dalam empat point. Keempat point tersebut adalah:

1. Agar manusia dapat berkembang secara serasi dan optimal unsur raga dan rohani serta jiwanya berdasarkan ajaran Islam.

2. Agar unsur rohani serta jiwa pada individu dapat berkembang secara serasi dan optimal.

3. Agar berkembang secara serasi dan optimal unsur kedudukan individu dan sosial, berdasar atas ajaran Islam.

4. Agar berkembang secara serasi dan optimal unsur manusia sebagai makhluk yang sekarang hidup di dunia dan kelak akan hidup di akhirat berdasarkan atas ajaran Islam.

\section{Kesehatan Mental}

Sehat (health) secara umum dapat dipahami sebagai kesejahteraan secara penuh (keadaan yang sempurna) baik secara fisik, mental, maupun secara sosial, dan tidak hanya terbebas dari penyakit atau keadaan lemah. Sedangkan di Indonesia UU Kesehatan No.23/1992 menyatakan bahwa sehat adalah suatu keadaan sehat secara fisik, mental, dan sosial di mana memungkinkan setiap manusia untuk hidup produktif baik secara sosial maupun ekonomis (Dewi, 2012: 10). Pepkin's dalam Arif Sumantri menjelaskan bahwa sehat adalah suatu keadaan keseimbangan yang dinamis antara bentuk tubuh dan fungsinya yang dapat mengadakan penyesuaian, sehingga dapat mengatasi gangguan dari luar (Sumantri, 2010: 295).

Menurut Kartono, pribadi yang normal atau yang bermental sehat adalah pribadi yang menampilkan tingkah laku yang kuat dan bisa diterima masyarakat pada umumnya, 
kemudian sikap hidupnya sesuai pola dan norma hidup kelompok masyarakat, sehingga ada relasi interpersonal dan intersosial yang memuaskan. Sedangkan menurut Karl Menninger, pribadi yang sehat mentalnya adalah mereka yang memiliki kemampuan untuk menahan diri, menunjukkan kecerdasan, berperilaku dengan menenggang perasaan orang lain, serta memiliki sikap hidup yang bahagia (Dewi, 2012: 11).

Zakiah Daradjat mendefinisikan pribadi yang sehat dengan cara menggabungkan peran agama di dalamnya. Menurutnya, pribadi yang sehat adalah pribadi yang mempunyai keserasian sungguh-sungguh antara fungsi fisik dan jiwanya, sehingga dapat menciptakan penyesuaian diri bagi dirinya, orang lain, dan lingkungannya yang berlandaskan keimanan dan ketakwaan untuk mencapai hidup bermakna serta bahagia di dunia dan di akhirat (Sholeh dan Musbikin. 2005: 25).

Selama berabad-abad pembahasan dan penelitian secara ilmiah terus dilakukan untuk menemukan penjelasan mengenai penyakit mental. Seiring berjalannya waktu, para peneliti mengeksplorasi bagaimana beragam penyakit fisik dapat memengaruhi fungsi mental, dan sebagian lagi mempelajari hubungan-hubungan yang mungkin antara stresor psikososial dan kesehatan mental. Pada abad terakhir ini, definisi gangguan mental telah berkembang hingga mencakup perspektif yang lebih kompleks tentang fungsi psikologis, serta mempertimbangkan pula masalah-masalah budaya dan lingkungan yang dapat memengaruhi fungsi kesehatan hidup manusia (Sholeh dan Musbikin. 2005: 239-240).

Kesehatan sangat diperlukan seseorang dalam menjalani kehidupan, baik kesehatan fisik maupun kesehatan mental. Dalam buku-buku kesehatan mental (mental hygiene) disebutkan bahwa, kepribadian yang mantap yaitu kepribadian yang mampu menyesuaikan diri dengan lingkungan dan sehat mental. Kesehatan mental dan penyesuaian diri yang baik merupakan dasar kebahagiaan seseorang. Antara kesehatan jasmani (fisik) dan kesehatan jiwa (mental) terjadi korelasi yang erat, sehingga kesehatan jasmani sangat menunjang menuju kesehatan ruhani (mental). Dalam bahasa Latin disebutkan, man sana in corpore sano (dalam badan yang sehat terdapat jiwa yang sehat). Dan dalam bahasa Arab disebutkan, al-aqlus salim fil jismis salim (akal yang sehat terdapat dalam tubuh yang sehat). Kedua pernyataan tersebut menunjukkan bahwa antara keduanya hendaklah dipertahankan keutuhannya, artinya sehat jasmani dan sehat ruhani harus sama-sama dijaga (Amin, 2013: 142-143).

Sementara itu, kesehatan mental menurut World Health Organization (WHO) adalah suatu keadaan yang bebas dari ketegangan dan kecemasan. Menerima kekecewaan sebagai pelajaran di kemudian hari, dapat menyesuaikan diri secara konstruktif pada kenyataan meskipun kenyataan itu pahit. Dapat berhubungan dengan orang lain serta dapat tolong menolong terhadap sesama. Merasa lebih puas memberi daripada menerima (Mulyadi, 2017: 1). Pendefinisian kesehatan mental yang dirumuskan oleh organisasi kesehatan sedunia ini kemudian menjadi rumusan undang-undang kesehatan mental di Indonesia. Pada tahun 1959 organisasi kesehatan dunia (WHO) (dalam Mulyadi, 2017: 17-18) memberikan batasan mental yang sehat sebagai berikut: 
1. Dapat menyesuaikan diri secara konstruktif pada kenyataan meskipun kenyataan itu buruk baginya.

2. Memperoleh kepuasan dari hasil jerih payah usahanya.

3. Merasa lebih puas memberi daripada menerima.

4. Secara relatif bebas dari tegang dan cemas.

5. Berhubungan dengan orang lain secara tolong menolong dan saling memuaskan.

6. Menerima kekecewaan sebagai pelajaran di kemudian hari.

7. Menjuruskan rasa permusuhan pada penyelesaian yang kreatif dan konstruktif.

8. Mempunyai rasa kasih sayang yang besar.

Kriteria tentang batasan mental sehat yang dikemukakan WHO pada tahun 1959 tersebut di atas, akhirnya pada tahun 1984 disempurnakan dengan menambahkan satu elemen spiritual (agama). Oleh karena itu, yang dimaksud dengan sehat adalah mencakup dari segi fisik, psikologi, sosial, dan sehat juga dalam arti spiritual atau agama (Sururin, 2004: 145). Berkenaan dengan hal di atas tersebut, di dalam Islam, sejak zaman Nabi pun sudah mengajarkan pentingnya menjaga dan memelihara kesehatan. Banyak ayat Al-Qur'an dan hadits serta kitab-kitab klasik yang menjelaskan tentang tuntunan Nabi berkaitan dengan kesehatan. Maka tidak heran jika ditemukan bahwa Islam sangat kaya dengan tuntunan kesehatan, karena Islam menetapkan tujuan pokok kehadirannya untuk memelihara agama, jiwa, akal, jasmani, dan keturunan (Mulyadi, 2017: 27).

Dengan begitu, dapat dipahami bahwa Rasulullah dan para ulama terdahulu telah menganjurkan umatnya untuk menjaga kesehatan sesuai dengan anjuran Al-Qur'an. Kesehatan yang mesti dijaga adalah kesehatan fisik dan kesehatan mental. Kesehatan fisik merupakan kesehatan yang berhubungan dengan seluruh anggota badan seperti kulit, mata, jantung, hati, dan sebagainya (Basit, 2017: 21-22). Adapun kesehatan mental dalam Islam, menurut Zakiah Daradjat adalah terwujudnya keserasian sungguh-sungguh antara fungsifungsi kejiwaan dan terciptanya penyesuaian diri antara manusia dengan dirinya sendiri dan lingkungannya, berlandaskan keimanan dan ketakwaan serta bertujuan untuk mencapai hidup yang bermakna dan bahagia di dunia dan di akhirat (Sholeh dan Musbikin. 2005: 25).

Hasan Langgulung menyimpulkan kesehatan mental dalam Islam sebagai akhlak yang mulia. Oleh sebab itu, kesehatan mental didefinisikan sebagai keadaan jiwa yang menyebabkan merasa rela dan ikhlas serta tentram, ketika ia melaksanakan akhlak yang mulia. Langgulung menjelaskan bahwa kesehatan mental menurut Islam yaitu identik dengan ibadah atau pengembangan potensi diri yang dimiliki manusia, dalam rangka mengabdi kepada Allah dan agama-Nya untuk mendapatkan an-nafs al muthmainnah (jiwa yang tenang dan bahagia) dengan kesempurnaan iman dalam hidupnya (Hamdani dan Afifuddin, 2012: 238).

Mental yang sehat dalam Islam ditandai dengan ketenangan jiwa, akhlak mulia, kesehatan dan kekuatan badan, memenuhi kebutuhan dasar dengan cara baik dan halal, memenuhi kebutuhan spiritual dengan berpegangan teguh pada akidah, mendekatkan diri pada Allah SWT dengan menjalankan ibadah dan melakukan amal shaleh, dan menjauhkan 
diri dari keburukan yang dapat menyebabkan Allah SWT murka (Masganti, 2011: 165). Dengan demikian, paradigma sehat menurut WHO seperti yang telah dijelaskan di atas, yaitu sehat secara biologis, psikis, sosial, dan spiritual sejalan dengan konsep sehat yang ada dalam pandangan Islam. Paradigma sehat yang komprehensif tersebut akan berdampak baik dalam kehidupan manusia manakala kepribadian yang ada pada diri manusia disesuaikan dengan konsepsi ajaran Islam.

\section{Konseling Islami: Suatu Alternatif bagi Kesehatan Mental}

Ada banyak penelitian yang menunjukkan efek positif keagamaan terhadap kesehatan mental dan kebahagiaan spiritual. Agama mempunyai pengaruh yang sangat besar terhadap kesehatan mental individu. Dengan demikian dapatlah dikatakan bahwa individu tidak akan mencapai atau memiliki mental yang sehat tanpa agama. Bahkan akhir-akhir ini semakin erat hubungan antara dokter-dokter (terutama dokter jiwa) dengan agama (Rosmalina, 2017: 15). Ini membuktikan bahwa masalah kesehatan bukanlah persoalan bagi bidang kedokteran saja, karena persoalan fisik akan selalu berkait dengan dimensi kehidupan yang lain. Dan seperti yang telah dijelaskan sebelumnya, hal ini telah disadari oleh WHO yang memberikan definisi tentang kesehatan tidak hanya untuk kesehatan fisik saja, tetapi juga menyangkut kesehatan biologis, kesehatan psikis, kesehatan sosial, dan kesehatan spiritual (Subandi, 2013: 119).

Sebelum World Health Organization mendefinisikan kesehatan seperti yang telah dijelaskan di atas, Islam telah lebih dulu menyatakan bahwa seseorang dikatakan sehat bila ia bebas dari segala macam penyakit fisik, bebas dari gangguan dan penyakit kejiwaan, mampu menyesuaikan diri dengan lingkungan sosialnya, dan mampu merealisasikan berbagai potensi yang ada pada dirinya, seperti kemampuan dan bakat, sikap, sifat, serta keterampilan, sehingga menjadi benar-benar aktual dan bermanfaat baik di dunia maupun di akhirat (Basit, 2017: 23).

Konseling Islami sebagai suatu layanan pemberian bantuan terhadap seseorang dalam mengembangkan potensinya, seperti akal pikiran, kejiwaan, keimanan, serta membantu agar dapat menanggulangi masalah hidupnya dengan baik dan benar secara mandiri yang sesuai tuntunan Al-Qur'an dan Sunnah Rasulullah SAW merupakan salah satu jalan untuk membentuk manusia ideal yang sesuai dengan fitrahnya (Adz-Dzaky, 2001: 127). Melalui layanan kegiatan konseling Islami ini, segenap dimensi dan potensi kemanusiaan dapat terpelihara dari berbagai macam penyakit mental yang merusak. Dan dengan kegiatan konseling Islami segala potensi yang dimiliki oleh manusia diarahkan agar dapat teraktualisasi sebagaimana mestinya, serta mampu membawa setiap manusia tersebut untuk memperoleh ketenangan dan kebahagiaan sesuai dengan fitrah dan tujuan hidupnya (Ramayulis dan Mulyadi, 2016: 125).

Dengan demikian, layanan konseling Islami merupakan kebutuhan yang krusial bagi tiap individu dan masyarakat Islam di zaman modern ini. Sebagai salah satu pendekatan konseling yang dibangun berdasarkan atas ajaran agama, konseling Islami tentu saja 
mendasari keilmuannya dari Al-Qur'an dan Hadits. Dalam memandang keberadaan manusia, konseling Islami memandangnya secara komprehensif tanpa mengabaikan unsur yang utama pada manusia, seperti aspek spiritual. Yang dimaksud aspek spiritual dalam konseling Islami yaitu yang berhubungan dengan masalah ruh, semangat atau jiwa, religiusitas, yang berhubungan dengan keagamaan, keimanan, kesalehan, dan menyangkut nilai-nilai transendental (Amin, 2013: 197).

Integritas eksplisit pendekatan konseling Islami dapat dipandang telah menawarkan sumber daya bagi kesehatan atau kesejahteraan mental yang diperuntukkan bagi mereka yang beriman. Apabila kesuksesan konseling pada umumnya (non-religius) dapat dipandang bergantung pada sumber daya konselor dan klien, maka konseling Islami memperkenalkan tipe sumber daya ketiga, yaitu kekuatan transendental yang bersifat eksternal. Pelayanan konseling Islami adalah usaha untuk mengintegrasikan ide dari konseling dan agama, dengan tujuan mengembangkan pendekatan yang baru dan lebih efektif agar dapat meningkatkan iman, Islam, dan ihsan bagi setiap individu yang diberi konseling hingga menjadi pribadi yang utuh. Dan pada akhirnya diharapkan dapat hidup bahagia di dunia dan akhirat (Sutoyo, 2015: 207).

Pribadi yang utuh atau kemantapan kepribadian merupakan kerja fungsi-fungsi yang harmonis atau aspek-aspek kejiwaan yang meliputi kehidupan jasmaniah, psikologis, dan kehidupan sosial budaya. Keutuhan kepribadian dapat diukur melalui derajat keharmonisan kesehatan jasmani, psikologis, dan kehidupan ruhaniah. Keutuhan kepribadian (pribadi kaffah) itulah yang menentukan kesehatan dan kebahagiaan jiwa seseorang. Dalam kesehatan mental, pribadi yang utuh akan mampu menyesuaikan diri baik dengan dirinya, orang lain, maupun dengan lingkungannya. Kesehatan mental dan penyesuaian diri yang baik merupakan dasar kebahagiaan bagi seseorang (Amin, 2013: 142).

Seseorang yang mentalnya sehat akan bertingkah laku serasi, tepat, dan bisa diterima oleh masyarakat pada umumnya. Kemudian sikap hidupnya sesuai dengan norma dan pola hidup kelompok masyarakat, sehingga ada relasi interpersonal dan intersosial yang memuaskan. Sebaliknya, seseorang yang tidak sehat mentalnya secara relatif mereka jauh dari status integrasi, dan memiliki ciri inferior dan superior. Kompleks inferior ini misalnya terdapat pada penderita psikosis, neurosis, dan psikopat (Amin, 2013: 143).

Kesehatan mental secara relatif harmonis atau sangat dekat dengan integritas jasmaniah-ruhaniah yang ideal. Kehidupan psikisnya stabil, tidak banyak memendam konflik internal, suasana hatinya tenang dan imbang, serta jasmaninya selalu sehat. Mentalitas yang sehat dimanifestasikan dalam gejala; tanpa gangguan batin, dan posisi pribadinya seimbang, baik ke dalam (terhadap diri sendiri), maupun ke luar (terhadap lingkungan sosial) (Amin, 2013: 143).

Kecenderungan manusia untuk bertahan diri dan mengembangkan diri, serta kecenderungan memenuhi kebutuhan atau melengkapi diri sebagai makhluk biologis memang harus dipenuhi. Hal ini merupakan kebutuhan manusia terhadap nilai-nilai biologis. Manusia sebagai makhluk sosial psikologis memerlukan kebutuhan sosial psikologisnya. Hal ini hanya dapat terlaksana jika ia mampu hidup bersama orang lain sebagai sesama subjek. 
Ini merupakan kebutuhan manusia akan nilai manusiawi, nilai sosial, dan kultural. Dan sebagai makhluk ruhaniah, manusia pun memerlukan pemuasan kebutuhan ruhaniah. Hal ini merupakan kebutuhan manusia akan nilai ruhaniah. Ketiga level kebutuhan dalam kenyataannya tidak dapat dipisahkan secara jelas, karena ketiga-tiganya menyatu pada manusia (Amin, 2013).

Dalam pandangan Islam, keharmonisan hubungan manusia terdapat dua hal penting; pertama, hablun minallah, yaitu hubungan antara manusia dengan Tuhan (hubungan vertikal), dan kedua, hablun minannas, yaitu hubungan antara manusia dengan sesama manusia (hubungan horizontal). Dan kedua hubungan tersebut, baik hablun minallah maupun hablun minannas haruslah harmonis, antara keduanya harus sama-sama paralel sehingga terciptalah kedamaian dan ketenangan jiwa dalam diri seorang Muslim. Karena bagi seorang Muslim, tujuan hidupnya adalah untuk mengabdi atau beribadah kepada Allah SWT. Kebahagiaan tersebut akan tercapai apabila seorang Muslim mampu memahami, menghayati, dan mengamalkan kenikmatan-kenikmatan yang terdapat dalam beribadah, baik berupa melaksanakan perintah Tuhan maupun meninggalkan larangan-Nya. Penghayatan bahwa ia berasal dari Allah, untuk Allah, dan kembali berserah diri kepada Allah merupakan inti kehidupan Muslim yang bersifat dinamis. Derajat penghayatan tersebut merupakan ukuran bagi tingkatan kesehatan dan kebahagiaan jiwa seorang Muslim (Amin, 2013).

Pada pendekatan layanan konseling Islami, dimensi antara agama dan konseling sangat terasa. Sejumlah praktisi dan teoritikus konseling Islami memberi pernyataan bahwa konseling itu sendiri belum sempurna apabila tidak memberikan perhatian yang serius terhadap aspek spiritual eksistensi manusia. Apabila ditinjau lebih mendalam, baik secara eksplisit maupun implisit, layanan konseling Islami merupakan suatu layanan yang tidak hanya mengupayakan manusia untuk bermental sehat dan hidup sejahtera, melainkan juga yang dapat menuntun kepada hidup yang sakinah, batin merasa tenang dan tenteram karena selalu dekat dengan Tuhan Yang Maha Esa. Kenyataan ini menunjukkan bahwa layanan konseling terlebih dalam bidang keagamaan keberadaannya sangat diperlukan masyarakat secara luas. Oleh karena itu, layanan konseling Islami menjadi sangat penting sebagai alternatif dalam mengembangkan kesehatan mental bagi masyarakat modern saat ini.

\section{SIMPULAN}

Layanan konseling Islami merupakan bantuan berupa hubungan yang berbentuk dorongan dan pendampingan terhadap individu untuk belajar mengembangkan fitrah dan atau kembali kepada fitrahnya sebagai manusia, dengan cara memberdayakan iman dan akal serta semua kemampuan yang dimiliki setiap individu tersebut. Fokus konseling Islami ini berupa pengembangan fitrah iman yang ada pada individu, karena jika fitrah iman pada individu tersebut berkembang dan berfungsi dengan baik, maka ia mampu memberi arah, mendorong, dan mengendalikan fitrah lainnya seperti jasmani, rohani, dan nafs.

Konseling Islami ini bertitik tolak dari suatu pandangannya tentang hakikat dan fitrah manusia dalam perspektif Al-Qur'an, sehingga layanan konseling Islami lebih kepada suatu 
pendekatan yang bersifat religius dan spiritual. Esensi fitrah manusia dalam adalah beriman, yaitu mengakui keesaan Allah dan taat kepada-Nya, dengan berpegang pada esensi fitrah iman tersebut, setiap manusia dapat mencapai kodratnya yang tertinggi dan mulia. Proses pencapaian kodrat tertinggi pada manusia juga sekaligus merupakan proses pencapaian terhadap kesehatan jiwa yang optimal.

\section{DAFTAR PUSTAKA}

Adz-Dzaky, Hamdani Bakran. (2001). Psikoterapi dan Konseling Islam sebuah Kajian Sufistik. Yogyakarta: Fajar Pustaka Baru.

Amin, Samsul Munir. (2013). Bimbingan dan Konseling Islam. Jakarta: Amzah.

Anwar, M. Fuad. (2014). Landasan Bimbingan dan Konseling Islam. Yogyakarta: Depublish.

Basit, Abdul. (2017). Konseling Islam. Jakarta: Kencana.

Daradjat, Zakiah. (1990). Kesehatan Mental. Jakarta: CV Haji Mas Agung.

Dewi, Kartika Sari. (2012). Kesehatan Mental. Semarang: UNDIP Press.

Gladding, Samuel T. (2015). Counseling a Comprehensive Profession. Alih bahasa oleh P.M. Winarno. Konseling Profesi yang Menyeluruh. Jakarta: Indeks.

Hamdani dan Afifuddin. (2012). Bimbingan dan Konseling. Bandung: Pustaka Setia.

Lubis, Syaiful Akhyar. (2008). Pendidikan dalam Konseling Islam. Bandung: Cita Pustaka Media Pritis.

Lubis, Syaiful Akhyar. (2015). Konseling Islami: dalam Komunitas Pesantren. Bandung: Cita Pustaka Media.

Masganti. (2011). Psikologi Agama. Medan: Perdana Publishing.

McLeod, John. (2015). An Introduction to Counseling. Alih bahasa oleh A.K. Anwar. Pengantar Konseling: Teori dan Studi Kasus. Jakarta: Kencana.

Mubarok, Achmad. (2000). Konseling Agama Teori dan Kasus. Jakarta: Bina Rena Pariwara.

Mulyadi. (2017). Islam dan Kesehatan Mental. Jakarta: Kalam Mulia.

Musari. (2011). Bimbingan dan Konseling. Bandung: Pustaka Diamond.

Musnamar, Thohari. (1992). Dasar-dasar Konseptual Bimbingan dan Konseling Islami. Yogyakarta: UII Press. 
Prayitno dan Amti, Erman. (2013). Dasar-dasar Bimbingan dan Konseling. Jakarta: Rineka Cipta.

Ramayulis dan Mulyadi. (2016). Bimbingan dan Konseling Islam di Madrasah dan Sekolah. Jakarta: Kalam Mulia.

Rosmalina, Asriyanti. (2017). Bimbingan dan Konseling Islam dalam Kesehatan Mental. Cirebon: CV Elsi Pro.

Shihab, Quraish. (2013). Membumikan Al-Qur'an: Fungsi dan Peran Wahyu dalam Kehidupan Masyarakat. Bandung: Mizan.

Sholeh, Moh dan Musbikin, Imam. (2005). Agama Sebagai Terapi. Yogyakarta: Pustaka Pelajar.

Subandi. (2013). Psikologi Agama dan Kesehatan Mental. Yogyakarta: Pustaka Pelajar.

Sumantri, Arif. (2010). Kesehatan Lingkungan dalam Perspektif Islam. Jakarta: Kencana.

Sururin. (2004). Ilmu Jiwa Agama. Jakarta: Raja Grafindo Persada.

Sutoyo, Anwar. (2015). Bimbingan dan Konseling Islami: Teori dan Praktik. Yogyakarta: Pustaka Pelajar.

Sutoyo, Anwar. (2015). Manusia dalam Perspektif Al-Qur'an. Yogyakarta: Pustaka Pelajar.

Yusuf, Syamsu dan Nurihsan, Juntika. (2005). Landasan Bimbingan dan Konseling. Bandung: PPS UPI dan Rosdakarya. 
226 | Muzaki \& Saputra - Konseling Islami: Suatu ... 